\title{
Effect of high-pressure treatment on hard cheese proteolysis
}

\author{
Luciana M. Costabel, ${ }^{\star 1}$ Carina Bergamini, $†$ Sergio R. Vaudagna, $¥ \S$ Alejandra L. Cuatrin, ${ }^{*}$ Gabriela Audero, ${ }^{*}$ \\ and Erica Hynes†\# \\ *Instituto Nacional de Tecnología Agropecuaria (INTA), Estación Experimental Agropecuaria Rafaela, Grupo Calidad de Leche y Agroindustria, \\ Ruta 34 Km 227, Rafaela, CP 2300, Santa Fe, Argentina \\ tInstituto de Lactología Industrial, Universidad Nacional del Litoral—CONICET, Santiago del Estero 2829, S3000AOM Santa Fe, Argentina \\ łInstituto Tecnología de Alimentos (ITA), CIA, INTA, CC77, CP B1708WAB, Morón, Bs. As., Argentina \\ $\S$ CONICET, Rivadavia 1917, Ciudad Autónoma de Buenos Aires, CP C1033AAJ, Argentina \\ \#Facultad de Ingeniería Química, Universidad Nacional del Litoral, Santiago del Estero 2829, S3000AOM Santa Fe, Argentina
}

\section{ABSTRACT}

The application of high hydrostatic pressure (HHP) treatment has been proposed to reduce the ripening time of cheese via modifications in the enzymatic activities or the substrate reactivity. Investigations on the effect of HHP on cheese proteolysis have been undertaken with either encouraging results or little effect according to the treatment conditions and the type of cheese, but information concerning the effect of HHP on the ripening of hard cooked cheese is still lacking. In this report, we describe the effect of HHP treatment on Reggianito cheese proteolysis. For that purpose, 1-d-old miniature cheeses $(5.5-\mathrm{cm}$ diameter and 6 -cm height) were treated at 100 or $400 \mathrm{MPa}$ and $20^{\circ} \mathrm{C}$ for 5 or $10 \mathrm{~min}$, and control cheeses in the trial were not pressurized. All cheeses were ripened at $12^{\circ} \mathrm{C}$ during 90 d. The HHP did not affect gross composition of the cheeses, but microbial load changed, especially because the starter culture count was significantly lower at the beginning of the ripening of the cheeses treated at 400 $\mathrm{MPa}$ than in controls and cheeses treated at $100 \mathrm{MPa}$. Cheeses treated at $400 \mathrm{MPa}$ for $10 \mathrm{~min}$ had significantly higher plasmin activity than did the others; the residual coagulant activity was not affected by HHP. Proteolysis assessment showed that most severe treatments (400 $\mathrm{MPa})$ also resulted in cheeses with increased breakdown of $\alpha_{\mathrm{S}^{-}}$and $\beta$-CN. In addition, nitrogen content in soluble fractions was significantly higher in cheeses treated at $400 \mathrm{MPa}$, as well as soluble peptides and free AA production. Peptide profiles and individual and total content of free AA in 60-d-old treated cheese were as high as in fully ripened control cheeses (90 d). Holding time had an effect only on pH-4.6-soluble nitrogen fraction and plasmin activity; cheese treated for

Received June 3, 2015.

Accepted February 14, 2016.

${ }^{1}$ Corresponding author: costabel.luciana@inta.gob.ar
10 min showed higher values than those treated for 5 min, at both levels of pressure assayed. We concluded that HHP treatments at $400 \mathrm{MPa}$ applied $1 \mathrm{~d}$ after cheesemaking increased the rate of proteolysis, leading to an acceleration of the ripening process in Reggianito Argentino cheese, whereas 100-MPa treatments did not lead to significant changes.

Key words: high hydrostatic pressure, Reggianito cheese, ripening acceleration, proteolysis

\section{INTRODUCTION}

High hydrostatic pressure (HHP) treatment, a nonthermal method of food preservation used for a wide range of products, has similar benefits to thermal treatment in food safety while causing minimal changes in food quality (Torres and Velazquez, 2005). Research into the application of HHP processing dates back to the end of the 19th century when Hite (1899) demonstrated that the shelf life of milk could be extended by high-pressure treatment. However, the unavailability of suitable equipment hampered further research for the first half of the 20th century. The first HHP-treated products appeared on the market in Japan in 1991 (Cheftel, 1995). In milk and dairy products, the current state of knowledge on the subject is primarily derived from research done since 1990. In recent years, interest in the effect of HHP treatment on cheese has increased. The main objective is to accelerate cheese ripening and reduce the ripening time, during which the biochemical transformations of proteins, fats, and carbohydrates that will result in the texture, flavor, and functionality of different cheeses will proceed (Trujillo et al., 2000; O'Reilly et al., 2001).

The potential use of HHP treatment for the acceleration of cheese ripening was first studied by Yokoyama et al. (1992). These researchers claimed that cheese exposed to HHP treatment at $50 \mathrm{MPa}$ for $3 \mathrm{~d}$ at $25^{\circ} \mathrm{C}$ had characteristics typical of a 6-mo-old commercial Cheddar cheese. However, further studies in Cheddar 
(O'Reilly et al., 2000, 2001), Gouda (Messens et al., 1999), and goat cheese (Saldo et al., 2001) generally concluded that HHP treatments similar to those used by Yokoyama et al. (1992) had only minor effects on cheese ripening. These contradictory results were observed because the levels of starter bacteria added to the cheese milk by Yokoyama et al. (1992) were at least 10-fold higher than those used in the other studies, which probably influenced the acceleration of cheese ripening.

O'Reilly and colleagues studied the effect of different pressure ranges (50 to $400 \mathrm{MPa}$ ) and times both long (of the order of 3.5 and $81.5 \mathrm{~h}$ ) and short (under $20 \mathrm{~min}$ ) in Cheddar cheese (O'Reilly et al., 2000, 2002, 2003). Overall, these researchers determined that whereas cheese treated at low pressures and long holding times ( 50-200 MPa during up to $82 \mathrm{~h}$ ) had increased levels of primary proteolysis, HHP treatment at higher pressures for relatively shorter processing times (200-400 $\mathrm{MPa}$ for $\sim 20 \mathrm{~min}$ ) produced changes primarily in the protein structure, which improved the functional properties. These authors also found that the time during ripening in which the HHP treatment was applied also influenced the results, exhibiting stronger effects when the HHP treatment was applied to 1-d-old cheeses than to 15-d-old cheeses. Also for Cheddar cheese, studies performed by Rynne et al. (2008) using a pressure level of $400 \mathrm{MPa}$ for $10 \mathrm{~min}$ had little effect on primary proteolysis compared with control cheeses. Ozturk et al. (2013a) studied the effect of pressure levels between 50 and $400 \mathrm{MPa}$ and holding times of 5 and $20 \mathrm{~min}$ in reduced-fat Cheddar cheese. These researchers concluded that HHP treatment did not change the rate of proteolysis but improved the texture of the cheese. No change in the indexes of proteolysis was encountered when a treatment of $405 \mathrm{MPa}$ for 3 min was applied on regular and reduced, low, and no salt added Cheddar cheeses, but certain microbiological, textural, and rheological properties were affected by HHP (Ozturk et al., 2013b). Similar results in proteolysis were observed in Edam cheese, where a pressure level between 200 and $500 \mathrm{MPa}$ for a holding time of $30 \mathrm{~min}$ did not alter the rate of proteolysis, but treated cheese had an improvement of the consistency compared with control cheeses (Iwaczak and Winiewska, 2005). In a hard uncooked cheese, in which pressure levels between 200 and $500 \mathrm{MPa}$ were applied for $10 \mathrm{~min}$, an increase in the rate of proteolysis at $300 \mathrm{MPa}$ was observed (Yang et al., 2014). In Mozzarella cheese, HHP treatment at $400 \mathrm{MPa}$ for $5 \mathrm{~min}$ had no effect on the composition and functional properties (Sheehan et al., 2005). Studies in hard goat cheese treated at $400 \mathrm{MPa}$ showed an increase in the rate of proteolysis and changes in the composition of the HHP-treated cheese with respect to controls, although no change in plasmin activity and a decrease in the activity of the residual coagulant were observed (Saldo et al., 2002). In sheep cheeses, HHP treatment at $300 \mathrm{MPa}$ for 10 min $1 \mathrm{~d}$ after manufacture resulted in an increase in the rate of proteolysis, higher levels of free AA (FAA), and an improvement in the texture of the cheese compared with controls (Juan et al., 2008). Brie cheese and blue-veined cheese, treated at 400 and $600 \mathrm{MPa}$ for 5 and $10 \mathrm{~min}$, respectively, exhibited a decrease in microbial counts compared with the control cheese (Voigtet et al., 2010; Calzada et al., 2014). In addition, these researchers observed decelerated proteolysis of HHP-treated cheeses.

Different combinations of pressure level and holding time have been applied in several types of cheeses. Regarding hard cheeses, most studies have investigated Cheddar cheese and hard sheep cheeses. However, hard cooked cheeses, such as Parmigiano Reggiano, Grana Padano, Sbrinz, or Reggianito, that are ripened for periods ranging from 6 mo to $2 \mathrm{yr}$ have not been subjected to HHP to date. Technological approaches to accelerate the ripening of hard cooked cheeses is a topic of interest in dairy technology, as keeping large volumes of cheese for such a long period is both expensive and time consuming.

Reggianito is a hard cooked cheese derived from Italian Grana and Parmesan cheeses. This cheese has existed in Argentina since the late 19th century. Italian immigrants first produced Reggianito cheese, which has since diverged from the original varieties but is also different from Parmesan-like American or generic products (Zannoni et al., 1994). Reggianito has a higher moisture content (between 31.3 and 34.9\%), smaller size (between 5 and $10 \mathrm{~kg}$ of weight), and shorter ripening period (minimum $6 \mathrm{mo}$ ) than Italian hard cheeses, who have a moisture between 29.9 and $31.7 \%$, weight of $37 \mathrm{~kg}$ on average, and minimum ripening time of $12 \mathrm{mo}$ (Zannoni et al., 1994; Sihufe et al., 2012). Reggianito cheese is the most important hard cheese variety manufactured in Argentina, and it is exported primarily to Brazil, Russia, the United States, Chile, and Venezuela.

In this work, we studied the effect of pressure level (100 and $400 \mathrm{MPa}$ ) and holding time (5 and $10 \mathrm{~min}$ ) on Reggianito cheese proteolysis.

\section{MATERIALS AND METHODS}

\section{Experimental Design}

We assessed the influence of pressure and holding time on Reggianito cheese proteolysis. Both factors were studied at 2 levels (pressure: 100 and $400 \mathrm{MPa}$; holding time: 5 and $10 \mathrm{~min}$ ), which accounted for 4 treatments: T1 (100 MPa, $5 \mathrm{~min})$, T2 (100 MPa, $10 \mathrm{~min})$, T3 
(400 MPa, 5 min), and T4 (400 MPa, $10 \mathrm{~min}$ ). Control cheeses (unpressurised) were also included. Four replicates of the cheese makings were performed, with different milk. Cheeses were pressurized on the first day after cheesemaking.

\section{Cheesemaking}

Experimental Reggianito Argentino cheeses were manufactured according to the standard process (Gallino, 1994), using miniature molds. The use of miniature molds was needed to obtain miniature cheeses with optimum size for introduction into the vessel of the equipment used for HHP treatment. We made 4 replicate cheesemaking experiments using different milk batches, and on different days. Cow's milk was obtained from a dairy farm of Instituto Nacional de Tecnología Agropecuaria (Estación Experimental Agropecuaria Rafaela, Santa Fe, Argentina; mean compositional values \pm SD were as follows: $3.62 \pm 0.06 \%$ fat; $3.50 \pm 0.07 \%$ protein; $12.68 \pm 0.06 \%$ total solid; $\mathrm{pH}$ $6.81 \pm 0.06)$. Cheesemaking was performed in a $180-\mathrm{L}$ vat provided with automated variable-speed cutting and stirring devices (Industria Metalúrgica en Acero Inoxidable, IMAI, Rafaela, Santa Fe, Argentina). After adjusting fat content to a fat-protein ratio of 0.7 , milk was batch pasteurized at $65^{\circ} \mathrm{C}$ for $20 \mathrm{~min}$ and cooled to $32^{\circ} \mathrm{C}$, and $\mathrm{CaCl}_{2}$ was added at a final concentration of $0.02 \%$ (wt $/ \mathrm{vol}$ ). Milk pH was adjusted to the target value for Reggianito cheeses $(6.25 \pm 0.02)$ with lactic acid $(1.5 \% \mathrm{vol} / \mathrm{vol})$; after that a commercial starter composed of mixed strains of Lactobacillus helveticus (Chr. Hansen Argentina, Quilmes, Argentina) was added in a concentration of $10^{6} \mathrm{cfu} / \mathrm{mL}$ of milk. Milk clotting enzyme was pure chymosin (Chy-Max, Chr. Hansen Argentina, 570 international milk clotting units/ $\mathrm{mL}$ ); it was added to the milk immediately after the starter at a concentration of $0.06 \mathrm{~mL} / \mathrm{L}$ of milk. Next, a hot wire viscosity sensor (INRA, Pignat, France) was introduced into the vat, and the coagulation time was detected using de Coag software (INRA). This sensor measures the time between the coagulant addition and the beginning of milk clotting. The coagulation time was $7.18 \pm 0.66$ min (mean value $\pm \mathrm{SD}$ ), after which the curd was allowed to strengthen up for $2.16 \pm 0.20$ min, and then it was subsequently cut to the adequate grain size (approximately 1-3 $\mathrm{mm}$ ) with an automated device for curd cutting and stirring coupled to the vat. The mixture of the curd particles and whey was gently stirred and heated at $0.5^{\circ} \mathrm{C} / \mathrm{min}$ until it reached $42^{\circ} \mathrm{C}$ to reduce moisture in curd grains, and it was subsequently held at this temperature for $15 \mathrm{~min}$. The mixture was then more rapidly heated to $51^{\circ} \mathrm{C}\left(1^{\circ} \mathrm{C} / \mathrm{min}\right)$. When this temperature was reached, the mixture of whey and curds was kept for 3 min (cooking step). After that, the curds were separated from the whey and placed in miniature cylindrical molds that were $5.5 \mathrm{~cm}$ in diameter and $10 \mathrm{~cm}$ in height. From each vat, 40 minicheeses were obtained. The average cheese weight was $250 \mathrm{~g}$. Next, cheeses were pressed at room temperature $\left(20^{\circ} \mathrm{C}\right)$ in a horizontal press for $20 \mathrm{~h}$ and brined for $6 \mathrm{~h}$ in saturated brine at $12^{\circ} \mathrm{C}$. After that, minicheeses were vacuum packed using Cryovac BB2800CB bags (permeability to $\mathrm{O}_{2}$ at $3 \times 10^{-4} \mathrm{~cm}^{3} \mathrm{~m}^{-2} 24 \mathrm{~h}^{-1} \mathrm{~Pa}^{-1} ; \mathrm{CO}_{2}$ at 15 $\times 10^{-4} \mathrm{~cm}^{3} \mathrm{~m}^{-2} 24 \mathrm{~h}^{-1} \mathrm{~Pa}^{-1}$; and water vapor at $20 \mathrm{~g} \cdot 24$ $\mathrm{h}^{-1} \cdot \mathrm{m}^{-2}$; Sealed Air Co., Buenos Aires, Argentina). The 40 cheeses obtained by cheesemaking were randomly divided in control, T1, T2, T3, and T4 (8 for each treatment, including control).

\section{High-Pressure Processing}

Vacuum-packed 1-d-old cheeses were subjected to HHP treatment, applied in a High Pressure System Stansted Fluid Power Ltd. model Iso-Lab FPG9400:922 (Stansted, United Kingdom), with a vessel working volume of $2 \mathrm{dm}^{3}$ (maximum working pressure: 900 $\mathrm{MPa}$; temperature range: -20 to $\left.120^{\circ} \mathrm{C}\right)$. A mixture of propylene glycol and water (30:70) was used as compression fluid. Pressurization rate was $300 \mathrm{MPa} /$ min. The conditioning temperature of vessel and initial temperature of compression fluid was $20^{\circ} \mathrm{C}$. The adiabatic heating induced an increase of temperature that reached a maximum at $400 \mathrm{MPa}$. In this case, the fluid temperature increased up to $30^{\circ} \mathrm{C}$ at the end of the compression stage. After HHP treatment, the packages of the cheese were removed, and all cheeses (pressurized and control) were ripened $90 \mathrm{~d}$ at $85 \%$ relative humidity and $12^{\circ} \mathrm{C}$. After the first 2 wk of ripening, all cheeses were vacuum packed again with the same bags described above to avoid over drying. This time was selected according to a previous experiment for the validation of the model (Vélez, 2013), in which it was assessed that the moisture content of the miniature cheeses reached levels of 34 to $35 \%$, similar to commercial Reggianito cheese at the end of ripening, after 2 wk of ripening. One cheese of each treatment, including control cheese, was selected randomly on d 1 , 45, and 90 after treatments and was completely grated. Then, grated cheese samples were taken and were immediately analyzed for gross composition and $\mathrm{pH}$ or stored at $-18^{\circ} \mathrm{C}$ for further analysis.

\section{Cheese Analysis}

All assays were performed in duplicate at 1,45 , and $90 \mathrm{~d}$ after HHP treatment. 
Gross Composition of Cheeses and Microbiological Counts. Total protein, fat, and DM were assessed according to International Dairy Federation standards (IDF, 1982, 1993, 1997). The results of total protein and fat were expressed in DM. The $\mathrm{pH}$ was determined as described by Bradley et al. (1993) by immersing of the electrode (Schott Instrument, Mainz, Germany) in a homogenate (1:1) of grated cheese thoroughly mixed with distilled water.

Mesophilic and thermophilic lactobacilli were enumerated by counting the colonies on de Man, Rogosa, and Sharpe (MRS) agar plates (Laboratorios Britania, Buenos Aires, Argentina) after incubating the plates at 30 and $45^{\circ} \mathrm{C}$, respectively, for $48 \mathrm{~h}$ under microaerophilic conditions (Corsetti et al., 1998).

Residual Coagulant and Plasmin Activity. The residual coagulant activity in the cheese samples was assessed according to the method of Hurley et al. (1999), with some modifications as described by Costabel et al. (2015). This method quantifies the hydrolysis of a synthetic chromophoric heptapeptide substrate [Pro-ThrGlu-Phe-( $\mathrm{NO}_{2}$-Phe)-Arg-Leu; Bachem California Inc., Torrance, CA). From this substrate, aspartic proteases are able to release the tripeptide [( $\left.\left.\mathrm{NO}_{2}-\mathrm{Phe}\right)-\mathrm{Arg}-\mathrm{Leu}\right]$ in proportion with their activity; this tripeptide is then quantified by reverse-phase HPLC (RP-HPLC). The HPLC system consisted of a quaternary pump, an online degasser, and a UV/visible detector (all Series 200, Perkin Elmer, Norwalk, CT). An interface module connected to a computer was used for the acquisition of chromatographic data with the Turbochrom software (Perkin Elmer). The analysis was performed on an Aquapore OD-300 (C18, $5 \mathrm{~nm},-300 \AA$, $250 \mathrm{~mm} \times$ $4.6 \mathrm{~mm}$ ) analytical column (Perkin Elmer). The results were expressed as nanomoles of product per gram of sample (DM) per hour.

Plasmin activity in the cheeses was assessed using the method of Richardson and Pearce (1981). Briefly, this method assesses enzymatic activity on a nonfluorescent substrate, succinyl-L-alanyl-L-phenylalanyl-Llysyl-7-amido-coumarin (Sigma-Aldrich, St. Louis, $\mathrm{MO}$ ), which results in the fluorescent product 7-amido4-methyl-coumarin (AMC) after hydrolysis. The AMC production was detected by measuring fluorescence with a spectrofluorometer (Hitachi f-2000, Tokyo, Japan) for 30 min at 5 min intervals. The plasmin activity in the cheeses was calculated with a calibration curve obtained with known AMC concentrations and was defined as nanomoles of AMC released per gram (of DM) per minute at $\mathrm{pH} 7.5$ and $25^{\circ} \mathrm{C}$.

Proteolysis Assessment. Proteolysis was assessed by the techniques described below.

The cheese samples were treated to obtain a crude citrate extract from which soluble $\mathrm{N}$ fractions at $\mathrm{pH} 4.6$
(SN-pH 4.6) and in $12 \%$ (wt/vol) trichloroacetic acid (SN-TCA) were prepared (Gripon et al., 1975; Hynes et al., 2003). The $\mathrm{N}$ content in each fraction was determined by the macro-Kjeldahl method (IDF, 1993).

The insoluble residue at $\mathrm{pH} 4.6$ was analyzed by ureaPAGE in a Mini-Protean II cube (BioRad Laboratories, Hercules, CA) according to the method of Andrews (1983). The proteins were stained with Coomassie Blue G-250.

The HPLC equipment and the chromatographic column were the same as in the analysis of the residual coagulant activity. The water-soluble extracts of the cheeses were obtained, filtered through $0.45-\mu \mathrm{m}$ membranes (Millex, Millipore, São Paulo, Brazil), and injected into the HPLC instrument. Detection was performed at $214 \mathrm{~nm}$, the column temperature was $40^{\circ} \mathrm{C}$, and the flow rate was $1 \mathrm{~mL} / \mathrm{min}$. Separation was achieved using an increasing linear gradient of acetonitrile in water over 107 min (Hynes et al., 2003).

Individual FAA were determined on $12 \%$ (wt/vol) trichloroacetic acid-soluble filtrates prepared from $\mathrm{SN}-\mathrm{pH}$ 4.6 fraction according to the method described by Cattaneo et al. (2014). Next, the $\mathrm{pH}$ of $10 \mathrm{~mL}$ of the FAA extract was adjusted to 2.2 with $\mathrm{NaOH}$ and filtered using a syringe filter with a $0.2-\mathrm{mm}$ membrane. The FAA concentrations were determined using a Biochrom 30 series AA analyzer (Biochrom US, Holliston, MA). The light absorption was measured at $570 \mathrm{~nm}$. Calibration curves were obtained using an AA standard purchased from Sigma (18AA-Sigma). For quantification, peak areas were correlated with the concentrations according to calibration curves. The results were expressed as milligrams of AA per $100 \mathrm{~g}$ of cheese (DM).

\section{Statistics}

The time of ripening and treatment applied were selected as main factors for the analysis. The ANOVA on the variables measured during ripening used a repeated measurements model (PROC MIXED, SAS Ver. 9.2, SAS Institute Inc., Cary, NC). Significant interaction effects $(P<0.05)$ were handled by analyzing the effect (main or interaction) of the involved treatment factor separately at each time of ripening point within the nonreducible model using the technique of slicing (PROC MIXED, SAS Ver. 9.2). Least square difference test was used as a post hoc test for pair-wise comparisons in all ANOVA models $(\alpha=0.05)$.

Peptide profiles were analyzed by multivariate methods, including a fuzzy logic approach for data preprocessing for RP-HPLC chromatograms of peptide profiles (Piraino et al., 2004). Next, principal components analysis was applied to reduce dimensionality of peptide profiles. Principal components analysis was 
performed using the SPSS 10.0 software (SPSS Inc., Chicago, IL).

\section{RESULTS}

\section{Cheese Composition and $\mathrm{pH}$}

The HHP treatments of cheeses 1-d after cheesemaking did not significantly affect their gross composition and $\mathrm{pH}$, as measured at 1, 45, and $90 \mathrm{~d}$ after HHP treatment. The time of ripening affected the $\mathrm{pH}$ and moisture content (Table 1). The $\mathrm{pH}$ increased and the moisture decreased significantly $(P<0.05)$ during storage of all cheeses (control and HHP treatments). The decrease of moisture was expected because of water evaporation before vacuum packing of cheeses.

\section{Microbiological Counts}

Thermophilic lactobacilli (i.e., microbial counts on MRS at $45^{\circ} \mathrm{C}$ ), which represent mainly the starter of Lactobacillus helveticus, decreased significantly $(P<$ 0.05 ) in all cheeses during ripening time (Table 2). A significant interaction $(P<0.05)$ between the HHP treatment and the time of ripening was observed (Table 1). On d 1 after HHP treatment, microbial counts enumerated on MRS at $45^{\circ} \mathrm{C}$ were significantly lower $(P<0.05)$ in T3 and T4 cheeses than in control, T1, and T2 cheeses (Table 2), which suggested an effect of the treatment on the viability of the starter culture. However, no significant differences were found between control and HHP-treated cheeses both at 45 and $90 \mathrm{~d}$ of ripening.

For microorganisms grown on MRS at $30^{\circ} \mathrm{C}$, bacterial counts in both control and HHP-treated cheeses decreased significantly $(P<0.05)$ during the $90 \mathrm{~d}$ of the ripening period (Tables 1 and 2). A significant interaction $(P<0.05)$ between the HHP treatment and time of ripening was found (Table 1). For each time of ripening, a different trend was found. On d 1 after HHP treatment, microbial loads in T3 and T4 cheese were significantly $(P<0.05)$ lower than in the control and in T1 and T2 cheeses. An opposite trend was found after 45 and $90 \mathrm{~d}$ of ripening, with counts significantly $(P<0.05)$ higher for T3 and T4 than control, T1, and $\mathrm{T} 2$ cheeses (Table 2). Microbial counts on MRS at $30^{\circ} \mathrm{C}$ represent mainly mesophilic lactobacilli, but we considered that the thermophilic lactobacilli of the starter, whose optimal growth temperature is $45^{\circ} \mathrm{C}$, were not completely inhibited at $30^{\circ} \mathrm{C}$. So, at the end of ripening, as starter microorganisms decreased, probably the nonstarter lactic acid bacteria population was mainly enumerated in this condition.
Table 1. Significance of the effect of high hydrostatic pressure treatment on Reggianito cheese (F1), ripening time (F2), and their interaction on gross composition, $\mathrm{pH}$, thermophilic and mesophilic lactobacilli, plasmin activity, coagulant activity, soluble nitrogen (SN) fraction, Asp, and total free AA

\begin{tabular}{|c|c|c|c|}
\hline \multirow[b]{2}{*}{ Item } & \multicolumn{3}{|c|}{ Significance } \\
\hline & $\mathrm{F} 1$ & $\mathrm{~F} 2$ & $\mathrm{~F} 1 \times \mathrm{F} 2$ \\
\hline Protein in DM & NS & NS & NS \\
\hline Fat in DM & NS & $\mathrm{NS}$ & NS \\
\hline Moisture & NS & $*$ & NS \\
\hline $\mathrm{pH}$ & $\mathrm{NS}$ & * & NS \\
\hline Thermophilic lactobacilli & $*$ & $*$ & $*$ \\
\hline Mesophilic lactobacilli & NS & $*$ & $*$ \\
\hline Plasmin activity & $*$ & $\mathrm{NS}$ & NS \\
\hline Coagulant activity & NS & $*$ & NS \\
\hline SN-pH 4.6 & $*$ & $*$ & NS \\
\hline SN-TCA ${ }^{1}$ & $*$ & $*$ & NS \\
\hline AA Asp & $*$ & $*$ & NS \\
\hline Total free AA & NS & $*$ & NS \\
\hline
\end{tabular}

${ }^{1} \mathrm{TCA}=$ trichloroacetic acid.

$* P<0.05$.

\section{Plasmin and Residual Coagulant Activity}

The activities of plasmin and residual coagulant enzyme in the cheeses are shown in Table 2. Although plasmin activity had a tendency to decrease with ripening time, differences were not statistically significant (Table 1). Regarding HHP treatment, cheeses treated at $400 \mathrm{MPa}$ for $10 \mathrm{~min}$ had significantly $(P<0.05)$ higher plasmin activity than did the control and other HHP treatments. The residual coagulant activity increased significantly $(P<0.05)$ in all cheeses during ripening; therefore, HHP had no detectable effect in the level of residual coagulant activity.

\section{Proteolysis Assessment}

$\boldsymbol{S N}$. The nitrogen content in the different soluble fractions $(\mathrm{SN})$ increased significantly $(P<0.05)$ during cheese ripening (Table 1). Moreover, HHP had a significant $(P<0.05)$ influence on the $2 \mathrm{SN}$ fractions assessed. In this sense, the levels of the SN-pH 4.6 fraction in $\mathrm{T} 4$ cheese were statistically the same as those in T3 cheese but different in control, T1, and T2 cheeses. In addition, the levels of this fraction in T3 cheese were statistically the same as those in T2 cheese but different in controls and T1 cheeses (Figure 1a). On the other hand, when the holding time increased (from 5 to $10 \mathrm{~min}$ ), the levels of $\mathrm{SN}-\mathrm{pH} 4.6$ tended to increase for each level of pressure assayed. As for the SN-TCA, control cheese had a significantly $(P<0.05)$ lower level than all the HHP-treated cheeses, which, in turn, showed significant differences $(P<0.05)$ between 
cheeses pressurized at $100 \mathrm{MPa}$ and those pressurized at $400 \mathrm{MPa}$, which had the highest level (Figure 1b).

Interestingly, the cheeses treated by HHP at $400 \mathrm{MPa}$ reached similar values for both indexes of proteolysis as control cheeses, $30 \mathrm{~d}$ earlier (Figure 1). Control cheeses showed levels of SN-pH 4.6 of $13.08 \pm 0.87 \%$ and SNTCA of $10.53 \pm 0.65 \%$ at the end of ripening $(90 \mathrm{~d}$ ), and similar values were obtained for $\mathrm{T} 4$ and for $\mathrm{T} 3$ and $\mathrm{T} 4$ cheeses, respectively, at $60 \mathrm{~d}$ of ripening.

Electrophoresis. The electrophoretic profiles of the $\mathrm{pH} 4.6$-insoluble fraction of the cheeses of 2 replicate cheese makings are shown in Figure 2. The other 2 replicates were similar, and they are not shown. At the beginning of ripening (d 1 after HHP treatment), all electrophoretic profiles were similar. As was observed for the SN fractions, the profiles of the control and $100-\mathrm{MPa}$ HHP-treated cheeses showed lower levels of proteolysis than the 400-MPa HHP-treated cheeses at $45 \mathrm{~d}$. As visually observed, the intensity of the band of $\alpha_{\mathrm{S} 1}-\mathrm{I} \mathrm{f}(24-199)$ at $45 \mathrm{~d}$ was higher in the cheeses HHP treated at $400 \mathrm{MPa}$. At the end of ripening, the intensity of this band in all cheeses was similar.

Table 2. Values (means $\pm \mathrm{SE}$ ) of the 4 replicas of cheeses for gross composition (\%), pH, thermophilic and mesophilic lactobacilli, plasmin activity, coagulant activity, Asp, and total free AA

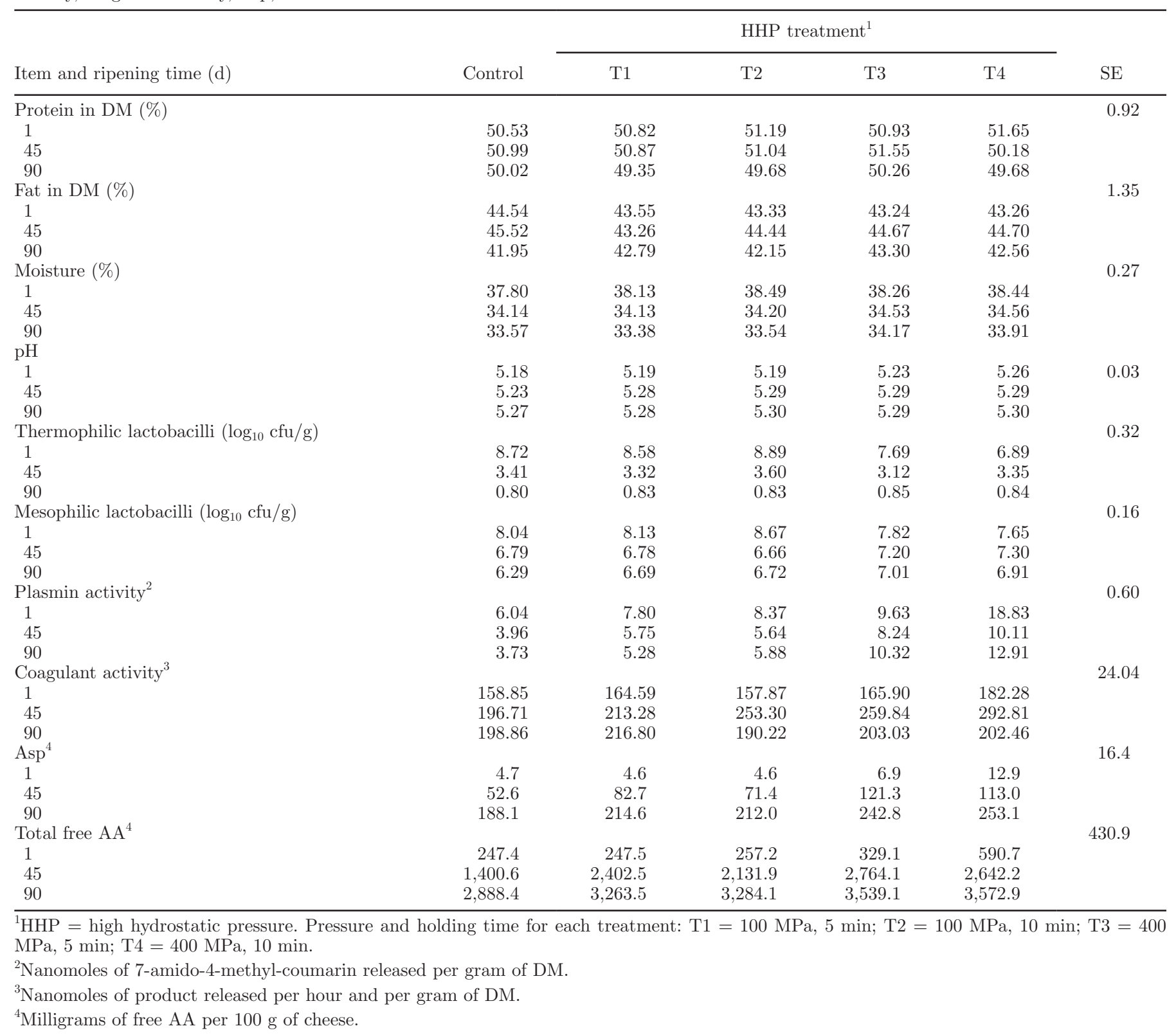


Regarding the breakdown products of $\beta-\mathrm{CN}$, higher intensity of the $\gamma-\mathrm{CN}$ fractions was found in cheeses HHP treated at $400 \mathrm{MPa}$ at $45 \mathrm{~d}$ of ripening.
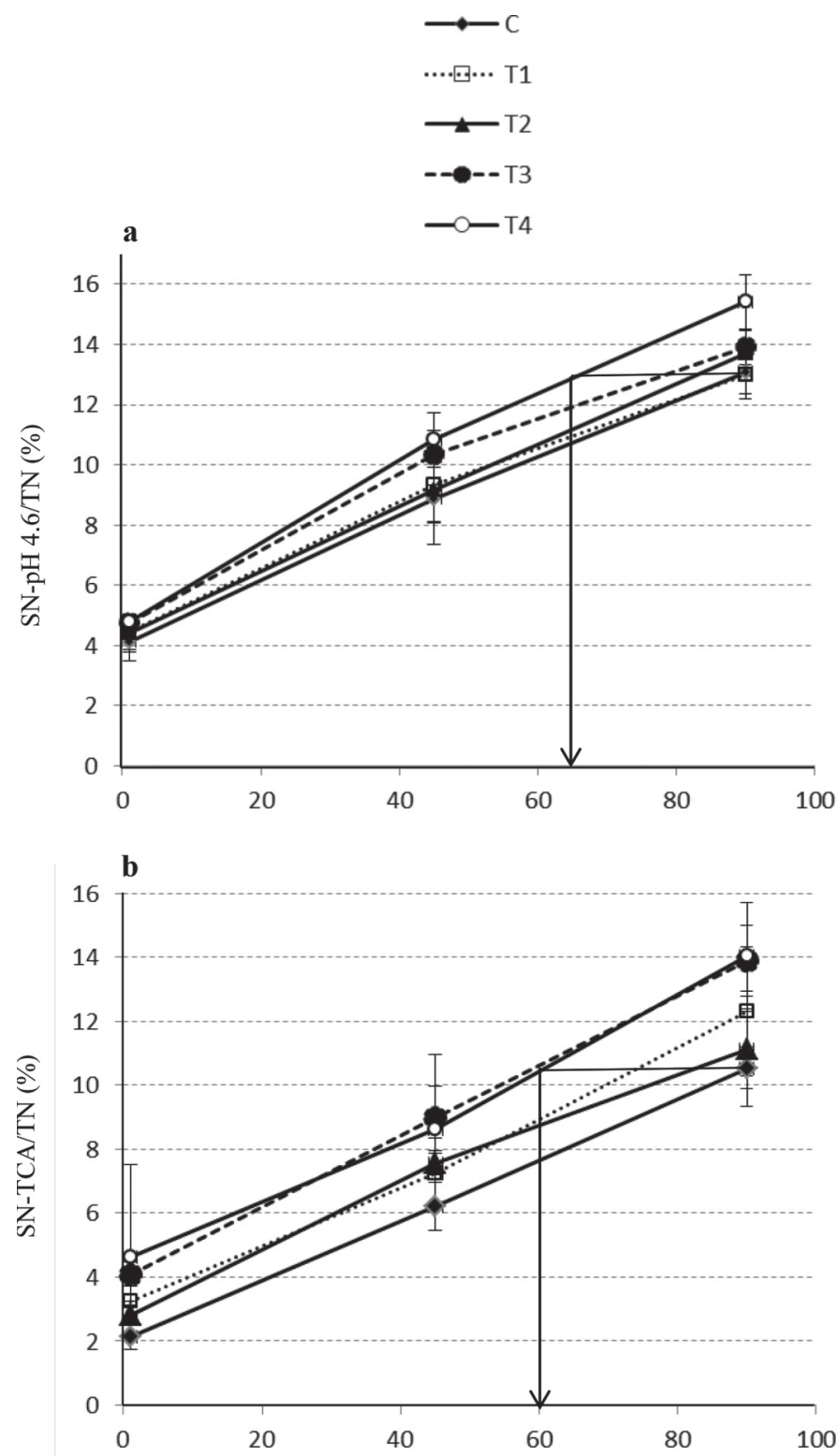

Ripening time (d)

Figure 1. Soluble nitrogen (SN) (a) at pH $4.6(\mathrm{SN}-\mathrm{pH} 4.6)$ and (b) in $12 \%$ (wt/vol) trichloroacetic acid (SN-TCA) expressed as the percentage of total $\mathrm{N}(\mathrm{TN})$ during ripening. For each ripening time, data points represent the mean $\pm \mathrm{SE}$ of 4 replicates. Arrows indicate the time at which the samples of cheeses treated with high hydrostatic pressure reached the same values of SN fractions as fully ripened control (C) cheeses. Pressure and holding time for each treatment: T1 = $100 \mathrm{MPa}, 5 \mathrm{~min} ; \mathrm{T} 2=100 \mathrm{MPa}, 10 \mathrm{~min} ; \mathrm{T} 3=400 \mathrm{MPa}, 5 \mathrm{~min} ; \mathrm{T} 4$ $=400 \mathrm{MPa}, 10 \mathrm{~min}$.
Peptide Profiles in Cheeses by RP-HPLC. Peptide profiles of all cheeses changed during ripening, with certain peak areas diminishing, whereas others increased (data not shown). The most evident change was the increase of peaks at the beginning of the chromatogram, which correspond to aromatic FAA - visible by UV detection in the condition of the assay - and hydrophilic peptides. The increase in the proportion of these compounds is the result of the usual evolution of proteolysis during ripening. Conversely, certain variations were found by visual comparison between peptide profiles of cheeses with different HHP treatments.

After variable reduction by fuzzy approach, peptide profiles were sorted into 19 classes of retention time, which were identified correlatively from $\mathrm{c} 1$ to $\mathrm{c} 19$. The areas of these classes were considered as input variables for principal components analysis, with standardization to a mean of zero and their original variances (covariance matrix). Two principal components (PC) with an eigenvalue higher than the mean of eigenvalues were extracted, which explained $96.2 \%$ of the total variance. Scores and loading plots for PC1 versus PC2 are presented in Figures $3 \mathrm{a}$ and $3 \mathrm{~b}$.

R1 R2

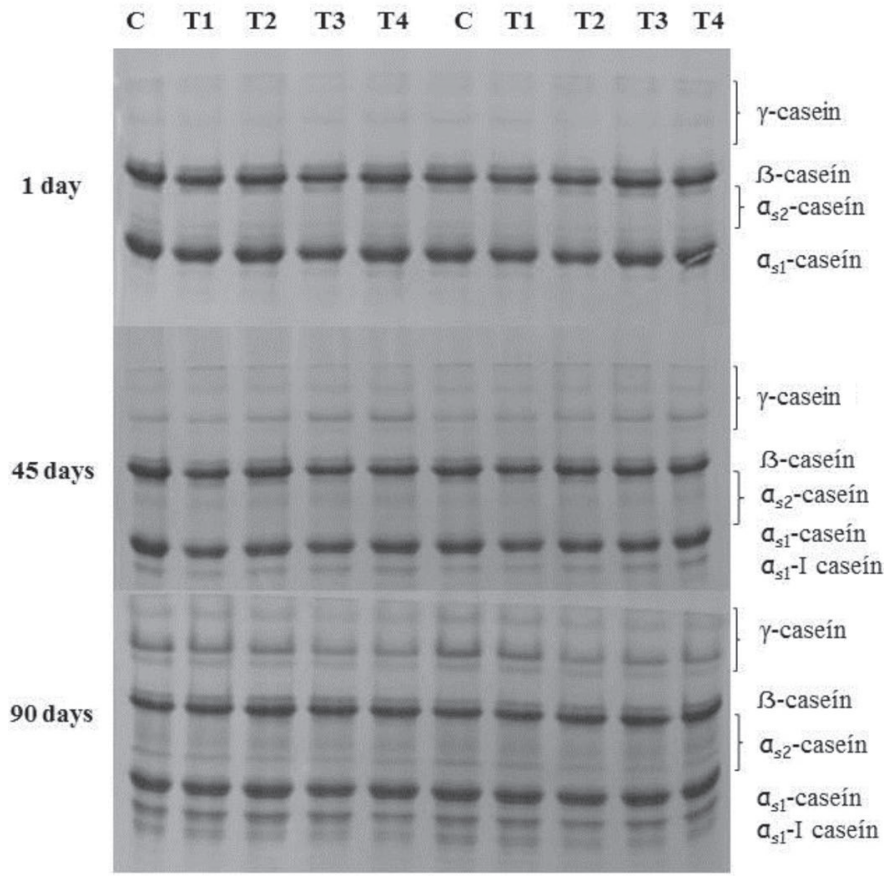

Figure 2. Electrophoretic profiles of insoluble cheese fractions at $\mathrm{pH} 4.6$ during ripening. $\mathrm{R} 1=$ replicate $1, \mathrm{R} 2=$ replicate 2 ; $\mathrm{C}=$ control. Pressure and holding time for each treatment: T1 $=100 \mathrm{MPa}, 5$ $\min ; \mathrm{T} 2=100 \mathrm{MPa}, 10 \mathrm{~min} ; \mathrm{T} 3=400 \mathrm{MPa}, 5 \mathrm{~min} ; \mathrm{T} 4=400 \mathrm{MPa}$, $10 \mathrm{~min}$. 
In the score plot, cheese samples are distributed along the first PC according to their ripening time. In this way, 1-d-old cheeses had negative scores on PC1, 45-d-old samples were near to zero, and 90-dold samples had positive scores. These results showed

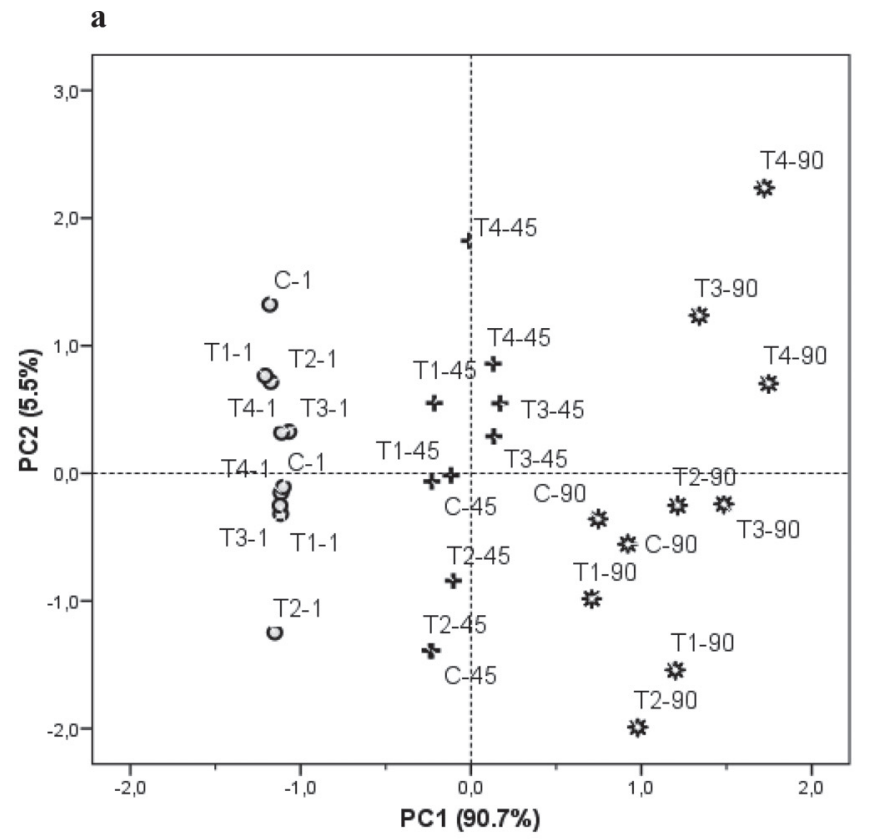

b

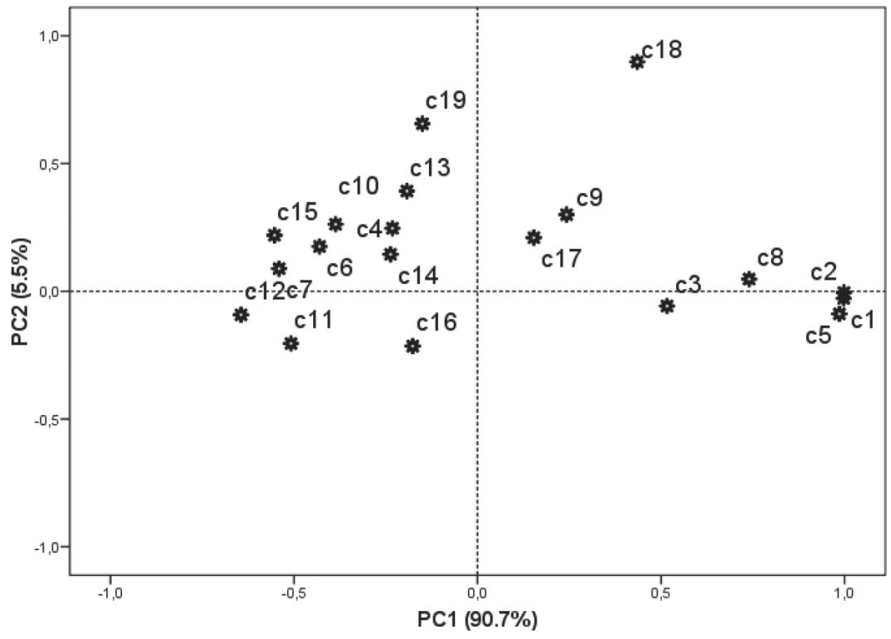

Figure 3. Principal component (PC) analysis of chromatographic profiles. (a) Score plot of samples at $1(\bigcirc), 45(+)$, and $90\left(^{*}\right)$ d of ripening on $\mathrm{PC} 1$ and $\mathrm{PC} 2$. Pressure and holding time for each treatment: $\mathrm{T} 1=100 \mathrm{MPa}, 5 \mathrm{~min} ; \mathrm{T} 2=100 \mathrm{MPa}, 10 \mathrm{~min} ; \mathrm{T} 3=400 \mathrm{MPa}$, 5 min; $\mathrm{T} 4=400 \mathrm{MPa}, 10$ min. (b) Loadings plots for $\mathrm{PC} 1$ versus $\mathrm{PC} 2$. Classes of retention time (c) were as follows: $\mathrm{c} 1=4.30 \mathrm{~min}, \mathrm{c} 2=8.45$ $\min , \mathrm{c} 3=12.60 \mathrm{~min}, \mathrm{c} 4=16.75 \mathrm{~min}, \mathrm{c} 5=20.90 \mathrm{~min}, \mathrm{c} 6=25.05 \mathrm{~min}$, $\mathrm{c} 7=29.20 \mathrm{~min}, \mathrm{c} 8=33.35 \mathrm{~min}, \mathrm{c} 9=37.50 \mathrm{~min}, \mathrm{c} 10=41.65 \mathrm{~min}$, $\mathrm{c} 11=45.80 \mathrm{~min}, \mathrm{c} 12=49.95 \mathrm{~min}, \mathrm{c} 13=54.10 \mathrm{~min}, \mathrm{c} 14=58.25 \mathrm{~min}$, $\mathrm{c} 15=62.4 \mathrm{~min}, \mathrm{c} 16=66.55 \mathrm{~min}, \mathrm{c} 17=70.70 \mathrm{~min}, \mathrm{c} 18=74.85 \mathrm{~min}$, and $\mathrm{c} 19=79.00$. that the principal source of variation between samples was the ripening time, as PC1 explained most of the total variance $(90.7 \%)$. Conversely, although samples of control and treated cheeses had similar scores on PC1 at $1 \mathrm{~d}$ of ripening, a separation between them was observed at 45 and $90 \mathrm{~d}$. Overall, cheeses subjected to the most severe treatment (T3 and T4) had higher scores on the first PC than the other cheeses with the same ripening time. Because $\mathrm{PC} 1$ is related to ripening time, the higher values of $\mathrm{PC} 1$ for $\mathrm{T} 3$ and $\mathrm{T} 4$ cheeses suggest an acceleration of proteolysis. Variables $\mathrm{c} 1, \mathrm{c} 2, \mathrm{c} 3$, $\mathrm{c5}$, and $\mathrm{c} 8$, which correspond with initial classes with retention time lower than 40 min (FAA and hydrophilic peptides), and also c18, whose retention time was 74.85 min, had higher loading on PC1, and so their increase is related to the increase of ripening time (Figure 3).

Conversely, HHP treatment had a clear influence on the sample scores on $\mathrm{PC} 2$, which explained $5.5 \%$ of variance. Overall, T3 and T4 samples, both at 45 and $90 \mathrm{~d}$ of ripening, showed higher scores on PC2 than the rest of samples at the same ripening time. Variables $\mathrm{c} 18$, c19, c13, and c9, which correspond with peaks that eluted in the middle and end of the chromatograms (hydrophobic peptides), showed the higher loading values on PC2 and thus are related to the applied treatment. These results reveal that HHP treatment at 400 $\mathrm{MPa}$, besides its effect on acceleration of ripening by increasing peptide levels that typically increase during ripening in this type of cheese, produces a differentiation in this process. This treatment also resulted in a preferential increase of characteristic peaks (Figure 3).

$\boldsymbol{F A A}$ Analysis. Results of statistical analysis and concentrations of aspartic and total FAA of all experiments are shown in Tables 1 and 2. Total FAA concentration increased with ripening time and showed the highest levels at $90 \mathrm{~d}$. This was also true for most individual FAA, except for Ala, His, and Trp, which increased to $45 \mathrm{~d}$ and then remained constant up to $90 \mathrm{~d}$ of ripening (data not shown). The HHP treatments of cheeses did not significantly affect the FAA profile, except for Asp, the levels of which significantly increased with the intensity of the HHP treatment. As observed for the SN fractions, samples of treatments T3 and $\mathrm{T} 4$ reached at $50 \mathrm{~d}$ of ripening levels of total FAA comparable to those of the control at $90 \mathrm{~d}$.

\section{DISCUSSION}

In the present work, we studied the effect of HHP treatment on the activity of plasmin and residual coagulant, as well as on the proteolysis and peptidolysis of Reggianito cheese. In addition, the effect of HHP 
treatment on gross composition, $\mathrm{pH}$, and microbial counts was investigated.

The composition of the cheeses was not significantly affected by HHP treatment. Moisture content was comparable for all samples. Similar results were reported by Rynne et al. (2008) in Cheddar cheeses, but other works reported higher moisture in several varieties of cheese at the end of ripening when they were treated at $300 \mathrm{MPa}$ or higher pressures (Saldo et al., 2000; Juan et al., 2008). In these cases, the higher moisture content at the end of ripening was attributed to changes in the casein network and higher water holding capacity in HHP-treated cheeses. In effect, the authors postulate that the increase in the levels of small peptides, which was verified in treated cheeses, led to a reduction in the loss of water that normally occurs during the ripening time. In our work, although T3 and T4 cheeses had higher moisture content on d 90 of ripening, the difference was not statistically significant, probably because the cheeses were vacuum packaged from d 12 onward, which prevented a subsequent drying of cheeses.

Regarding fat and protein, our results confirmed most previous research, which reported no changes attributable to HHP treatment (Saldo et al., 2002; Juan et al., 2008, Rynne et al., 2008; Moschopoulou et al., 2010). On the contrary, whereas several authors found differences in $\mathrm{pH}$ between standard and HHP-treated cheeses (Saldo et al., 2002; Rynne et al., 2008; Ozturk et al., 2013a), in our work the $\mathrm{pH}$ of cheeses was not affected by HHP treatment, though it increased significantly during ripening. The increase in $\mathrm{pH}$ during ripening of hard cheeses has been reported previously and is probably due to a combination of the proteolysis process and solubilization of insoluble calcium phosphate that occur during ripening (Lawrence et al., 1987).

The effect of HHP on the cheese microbiota was detected on d 1 after HHP treatment: thermophilic lactobacilli counts were lower in cheeses treated at 400 MPa than in the other cheeses, both controls and those treated at $100 \mathrm{MPa}$. Similar results were observed in Cheddar cheeses after HHP treatment at $400 \mathrm{MPa}$ (Wick et al., 2004; Rynne et al., 2008; Ozturk et al., 2013b), yeast-ripened cheeses (Voigt et al., 2010; Calzada et al., 2014), goat cheese (Saldo et al., 2000), and sheep cheeses (Moschopoulou et al., 2010). Unlike the starter used in this work, consisting of Lactobacillus helveticus strains, in Cheddar, goat, and sheep cheeses the starter was composed predominantly of strains of Lactococcus lactis. The effect of HHP treatment on microorganisms depends on the process conditions (compression rate, pressure level, holding time, and temperature), food characteristics (composition, $\mathrm{pH}$, and water activity), and the microorganism (genus, species, and strain)
(Cheftel, 1995; Huppertz et al., 2006). In real food systems, other factors play a role, because bacteria can recover after HHP treatment, which is often attributed to a protective effect by the food matrix (Wick et al., 2004). In fact, in Cheddar cheese with different salt concentrations (Ozturk et al., 2013b), it was observed that the effect of HHP on bacterial numbers increased with salt reduction, confirming the baroprotector effect of salt present in cheeses on bacteria. The decrease in microbial counts due to HHP treatment may indicate inhibition of growth of microorganisms, damage of the cell wall, or autolysis (Malone et al., 2002; O'Reilly et al., 2002). When autolysis of microorganisms occurs, the release of intracellular peptidases has a positive effect on cheese ripening acceleration (Wick et al., 2004). Juan et al. (2007) verified autolysis of a starter of Lactococcus lactis ssp. lactis and Lactococcus lactis ssp. cremoris due to HHP treatment, which was confirmed by increased activity of the cytoplasmic enzyme lactate dehydrogenase in the HHP-treated cheeses. Malone et al. (2002) showed that treatment with HHP caused inactivation, physical damage, and autolysis of the same Lactococcus lactis strain and that extent of lysis was dependent on the strain and the pressure level used. Holding time had no effect on bacterial counts, which was in agreement with the results of Ozturk et al. (2013a).

As ripening progressed, thermophilic microbial counts decreased in all cheeses, and differences between HHPtreated and control cheeses were no longer detected. A drastic reduction was found at $45 \mathrm{~d}$ from $10^{8}$ to $10^{7}$ $\mathrm{cfu} / \mathrm{g}$ on cheeses $1 \mathrm{~d}$ after HHP treatment to $10^{3} \mathrm{cfu} / \mathrm{g}$, and at the end of ripening, thermophilic lactobacilli was undetectable. Thermophilic lactobacilli loads at the beginning and end of ripening were comparable to those reported for Reggianito Argentino cheese by other authors (Candioti et al., 2002; Ceruti et al., 2014). Parmigiano Reggiano and Grana Padano cheeses, which are made with natural starters composed primarily of Lactobacillus helveticus, show similar trends as shown in this study, reducing levels to undetectable values at the end of ripening (Giraffa et al., 1997; Coppola et al., 2000), which is largely due to the autolytic activity of most strains of Lactobacillus helveticus (SadatMekmene et al., 2013; Gatti et al., 2014).

In this work, markers of Lactobacillus helveticus lysis, such as intracellular enzymes, were not assessed. However, a detailed description of the peptidolysis, which also constitutes an index of the activity of intracellular peptidases of lactic acid bacteria in cheese, was undertaken. In this sense, the early decrease in thermophilic lactobacilli population may have contributed to accelerated peptidolysis and was, in fact, consistent with 
an increase of global proteolysis observed in cheeses treated to $400 \mathrm{MPa}$, as discussed below.

Overall, during cheese ripening, the nonstarter lactic acid bacteria begins to prevail, while the number of lactic acid bacteria from the starter decreases (Sousa et al., 2001; Gatti et al., 2014). This trend was also verified in the present work. The counts of mesophilic lactobacilli at the end of ripening, which are mainly nonstarter lactic acid bacteria, were similar to those found in previous research on Reggianito Argentino cheese (Ceruti et al., 2014). The decrease in the number of mesophilic lactobacilli due to HHP treatment at $400 \mathrm{MPa}$ at the beginning of ripening was also found in other varieties of cheese when similar pressures were applied at $1 \mathrm{~d}$ after cheesemaking, as in our study (Juan et al., 2007; Rynne et al., 2008; Moschopoulou et al., 2010).

Plasmin and residual coagulant are proteolytic enzymes that are normally active in the cheese and involved in primary proteolysis. Previous studies have reported that the application of HHP treatment at the beginning of ripening can affect cheese ripening through modulation of enzymatic reactions (Messens et al., 1999; O'Reilly et al., 2000). In this work, plasmin activity in cheeses treated at $400 \mathrm{MPa}$ during $10 \mathrm{~min}$ was increased. This activation was not previously reported in cheeses. In Cheddar cheese, when a similar HHP treatment was applied, the activity of this enzyme was not affected by HHP treatment (O'Reilly et al., 2002; Huppertz et al., 2004; Rynne et al., 2008). Evidence exists that the application of low to moderate hydrostatic pressures (100 to $400 \mathrm{MPa}$ ) can increase the activity of proteolytic enzymes (Eisenmenger and Reyes-De-Corcuera, 2009), whereas higher pressures $(>400 \mathrm{MPa})$ can inactivate them (Huppertz et al., 2004). The range of pressures in which the HHP treatment can switch from positive to negative effects on the activity of an enzyme probably depends on the characteristics of the enzyme and the food matrix but also on other components of interest in the enzyme system. Plasmin has a complex system of precursors and inhibitors in the matrix milk, where the inactive precursor plasminogen is also included. Whereas some of these components are lost in the whey during cheesemaking, others are retained in the curd in a proportion depending on the technology applied for cheesemaking. In addition, the activation of plasminogen to different degrees is also dependent on the technology applied (McSweeney, 2004; Ismail and Nielsen, 2010). Therefore, it is difficult to compare the effect of a given HHP treatment among different varieties of cheese. As for the residual coagulant activity, it was not affected by HHP treatment, which agrees with data reported in previous studies (Messens et al., 1999; O'Reilly et al., 2002; Huppertz etal., 2004; Rynne et al., 2008).
$\alpha_{S 1}$-Casein is the most susceptible protein in the cheese matrix to the activity of coagulant enzyme during cheese ripening, and the primary site of attack is $\mathrm{Phe}_{23}-\mathrm{Phe}_{24}$ to produce peptides $\alpha_{\mathrm{S} 1} \mathrm{f}(1-23)$ and $\alpha_{\mathrm{S} 1}-\mathrm{I}$ f(24-199; Carles and Ribadeau-Dumas, 1985). As for plasmin, it is known that the preferential substrates are $\alpha_{\mathrm{s}^{2}} \mathrm{CN}$ and $\beta-\mathrm{CN}$, with the latter giving the C-terminal fragments known as $\gamma 1-\mathrm{CN}, \gamma 2-\mathrm{CN}$, and $\gamma 3-\mathrm{CN}$ (Rampilli and Raja, 1998). An increase in the concentration of $\gamma$-CN is considered an index of increased plasmin activity (Grufferty and Fox, 1988). In this work, all of the indexes of proteolysis assessed showed the same overall trend: this primary biochemical transformation of cheese ripening was influenced by HHP treatment. The effect was most evident when treatment at 400 $\mathrm{MPa}$ was applied, and it was verified for all the SN fractions and electrophoresis, with a higher intensity in $\alpha_{S_{1}-\mathrm{I}}$ fractions and $\gamma-\mathrm{CN}$ fractions, especially after 45 $\mathrm{d}$ of ripening. The greater intensity of $\gamma-\mathrm{CN}$ was consistent with an increased activity of plasmin in cheeses HHP treated at $400 \mathrm{MPa}$. Messens et al. (1998) also showed an increase in $\beta$-CN hydrolysis, even when they found no changes in plasmin activity in Gouda cheeses treated at $300 \mathrm{MPa}$. These authors attributed the differences to a conformational change in the structure of the casein as a result of the pressure, leading to greater exposure of susceptible bonds from $\beta-\mathrm{CN}$ that became readily cleavable by plasmin. Saldo et al. (2002) also found a higher concentration of the products of $\beta-\mathrm{CN}$ hydrolysis by plasmin in goat cheeses treated 5 min at $400 \mathrm{MPa}$; however, no difference was found in plasmin activity compared with control cheese. In this case, the authors explained this fact by the higher $\mathrm{pH}$ of the cheeses treated by HHP, which is closest of the optimum $\mathrm{pH}$ for this enzyme.

For the $\alpha_{\mathrm{S} 1}-\mathrm{I}$ fraction, the increase verified in our work did not correlate with increased residual coagulant activity because coagulant activity did not significantly differ between treatments. A similar trend was reported by Rynne et al. (2008).

Changes in cheese primary proteolysis attributable to HHP treatment were observed previously for different cheese varieties. Rynne et al. (2008) found an increased hydrolysis of $\alpha_{\mathrm{S1}^{-}} \mathrm{CN}$ and higher levels of $\mathrm{SN}-\mathrm{pH} 4.6$ in Cheddar cheese treated at $400 \mathrm{MPa}$ for $10 \mathrm{~min}$. Accelerated primary proteolysis was also reported for cheeses treated at $\sim 400 \mathrm{MPa}$ for goat cheese (Saldo et al., 2000), ewe milk cheese (Garde et al., 2007; Juan et al., 2007), and Gouda cheese (Messens et al., 2001). Contrary results were reported by Sheehan et al. (2005) in Mozzarella cheese that was similarly pressurized, which exhibited no changes in primary proteolysis. Ozturk et al. (2013a) found similar behavior in reducedfat Cheddar cheese, in which the pressure and holding 
time varied between 48 and $402 \mathrm{MPa}$ and 2.5 and 19.5 min, respectively. However, in this study, HHP was applied a week after cheesemaking, which suggested that cheese age is a relevant factor. In Edam cheese treated at pressures of 200 and $400 \mathrm{MPa}$ at 4,6 , or $8 \mathrm{wk}$ after cheesemaking, an initial decrease in the $\mathrm{SN}-\mathrm{pH} 4.6$ fraction after HHP treatment with respect to untreated control cheese was observed. However, at the end of ripening, SN levels of all cheeses were similar (Iwanczak and Wisniewska, 2005). In our study, the holding time had only an effect on SN fraction at $\mathrm{pH} 4.6$ and plasmin activity; cheese treated for 10 min showed higher values than those treated for $5 \mathrm{~min}$, at both levels of pressure assayed. In other works in which similar treatments were used, different holding times had no effects on primary proteolysis (Messens et al., 1999; Ozturk et al., 2013a). These results show that the physicochemical characteristics and the specific environmental conditions of different cheeses studied, as well as the time after cheesemaking in which the HHP treatment is applied, all have a strong effect on the effect of HHP treatment on cheese proteolysis.

The peptide profiles of our samples treated at the highest pressure also differed from the rest, which showed a higher secondary proteolysis in T3 and T4 cheeses. We also found an overall higher amount, although not significant, of total FAA when the pressure increased, but individual concentrations of FAA showed no change, with the exception of aspartic acid, the concentration of which was significantly higher in the cheeses treated at $400 \mathrm{MPa}$. This absent or notably small effect of HHP treatment on the levels of FAA was also observed by other authors in Cheddar cheese (O'Reilly et al., 2002; Rynne et al., 2008), Mozzarella (Sheehan et al., 2005), and Gouda (Messens et al., 1999). In ewe cheese, no effect of treatment in the level of total FAA was found for cheeses treated at pressures greater than $400 \mathrm{MPa}$, but the cheese treated at lower pressure (200 to $300 \mathrm{MPa}$ ) had higher levels of total FAA than the controls (Juan et al., 2007). It is important to consider that the content of FAA in a cheese is the result of the balance between their production from peptides and their catabolism. So, the effect of HHP treatment on the FAA levels could be masked if the activity of both peptidases and enzymes involved in the catabolism of FAA are increased.

\section{CONCLUSIONS}

The HHP treatment of Reggianito cheese had no influence on gross composition or $\mathrm{pH}$ at any time of ripening studied, and treatment at the highest pressure decreased starter counts and increased plasmin activ- ity. Consistently with these findings, proteolysis and peptidolysis were accelerated in the $400 \mathrm{MPa}$-treated cheeses, which were as proteolysed at $60 \mathrm{~d}$ of ripening as were the control unpressurized 90-d-old cheeses. Cheeses treated at $100 \mathrm{MPa}$ did not exhibit differences from unpressurized samples. According to the results obtained in our study, HHP treatment at $400 \mathrm{MPa}$ is promising to accelerate cheese ripening of hard cooked cheese. Because the pilot plant in which the study was conducted reproduces in small scale the processing conditions of a plant on a commercial scale, these results should be validated by means of experiences in large scale.

\section{ACKNOWLEDGMENTS}

This research work was funded by Instituto Nacional de Tecnología Agropecuaria (Buenos Aires, Argentina) and Universidad Nacional del Litoral (Santa Fe, Argentina).

\section{REFERENCES}

Andrews, A. T. 1983. Proteinases in normal bovine milk and their action on caseins. J. Dairy Res. 50:45-55.

Bradley, R. L., E. Arnold, D. M. Barbano, R. G. Semerad, D. E. Smith, and B. K. Vines. 1993. Chemical and physical methods. Pages 433-531 in Standard Methods for the Examination of Dairy Products. R. Marshall, ed. Am. Public Health Assoc., Washington, DC.

Calzada, J., A. del Olmo, A. Picon, P. Gaya, and M. Nuñez. 2014. Effect of high-pressure-processing on the microbiology, proteolysis, texture and flavour of Brie cheese during cheese ripening and refrigerated storage. Int. Dairy J. 37:64-73.

Candioti, M. C., E. R. Hynes, A. Quiberoni, S. B. Palma, N. Sabbag, and C. A. Zalazar. 2002. Reggianito Argentino cheese: Influence of Lactobacillus helveticus strains isolated from natural whey cultures on cheese making and ripening processes. Int. Dairy J. 12:923-931.

Carles, C., and B. Ribadeau Dumas. 1985. Kinetics of the action of chymosin (rennin) on a peptide bond of bovine $\alpha_{\mathrm{s} 1}$ casein. Comparison of the behaviour of this substrate with that of $\beta$ and $\alpha$ scasein. FEBS Lett. 185:282-286.

Cattaneo, F., J. E. Sayago, M. R. Alberto, I. C. Zampini, R. M. Ordoñez, V. Chamarro, A. Pazos, and M. I. Isla. 2014. Anti-inflammatory and antioxidant activities, functional properties and mutagenicity studies of protein and protein hydrolysate obtained from Prosopis alba seed flour. Food Chem. 161:391-399.

Ceruti, R. J., S. E. Zorrilla, N. G. Sabbag, S. C. Costa, and G. A. Sihufe. 2014. Effect of increased initial ripening temperature on the sensory characteristics of Reggianito cheese. Int. J. Dairy Technol. $67: 1-8$.

Cheftel, J. C. 1995. High-pressure, microbial inactivation and food preservation. Food Sci. Technol. (Campinas.) 1:75-90.

Coppola, R., M. Nanni, M. Iorizzo, A. Sorrentino, E. Sorrentino, C. Chiavari, and L. Grazia. 2000. Microbiological characteristics of Parmigiano Reggiano cheese during the cheesemaking and the first months of the ripening. Lait 80:479-490.

Corsetti, A., M. Gobbetti, E. Smacchi, M. DeAngelis, and J. Rossi. 1998. Accelerated ripening of Pecorino Umbro cheese. J. Dairy Res. 65:631-642.

Costabel, L. M., C. V. Bergamini, L. Pozza, F. Cuffia, M. C. Candioti, and E. Hynes. 2015. Influence of chymosin type and curd scalding 
temperature on proteolysis of hard cooked cheeses. J. Dairy Res. $82: 375-384$.

Eisenmenger, M. J., and J. I. Reyes De Corcuera. 2009. High pressure enhancement of enzymes: A review. Enzyme Microb. Technol. 45:331-347.

Gallino, R. 1994. Queso Reggianito Argentino: Tecnología de fabricación. Pages 244-287 in Tecnología de los Productos Lácteos. Medios Audiovisuales y Gráficos - CERIDE, ed. Diagramma S.A., Santa Fe, Argentina.

Garde, S., J. L. Arqués, P. Gaya, M. Medina, and M. Nuñez. 2007. Effect of high-pressure treatments on proteolysis and texture of ewes' raw milk La Serena cheese. Int. Dairy J. 17:1424-1433.

Gatti, M., B. Bottari, C. Lazzi, E. Neviani, and G. Mucchetti. 2014. Invited review: Microbial evolution in raw-milk, long-ripened cheeses produced using undefined natural whey starters. J. Dairy Sci. 97:573-591.

Giraffa, G., F. Mucchetti, F. Addeo, and E. Neviani. 1997. Evolution of lactic acid microflora during Grana cheesemaking and ripening. Microbiol. Aliments Nutr. 15:115-122.

Gripon, J. C., M. J. Desmazeaud, D. Le Bars, and J. L. Bergère. 1975. Etude du rôle des micro-organismes et des enzymes au cours de la maturation des fromages. II. Influence de la pressure commercial. Lait 55:502-516.

Grufferty, M., and P. Fox. 1988. Milk alkaline protease. J. Dairy Res. 55:609-630.

Hite, B. H. 1899. The effect of high pressure in the preservation of milk. Bull. West Virginia Agric. Exp. Stn. 58:15-35.

Huppertz, T., P. F. Fox, and A. L. Kelly. 2004. Susceptibility of plasmin and chymosin in Cheddar cheese to inactivation by high pressure. J. Dairy Res. 71:496-499.

Huppertz, T., M. Smiddy, V. K. Upadhyay, and A. L. Kelly. 2006. High-pressure-induced changes in bovine milk: A review. Int. J. Dairy Technol. 59:58-66.

Hurley, M. J., B. M. O'Driscoll, A. L. Kelly, and P. H. L. McSweeney. 1999. Novel assay for the determination of residual coagulant activity in cheese. Int. Dairy J. 9:553-558.

Hynes, E. R., C. V. Bergamini, V. B. Suárez, and C. A. Zalazar. 2003. Proteolysis on Reggianito Argentino cheeses manufactured with natural whey cultures and selected strains of Lactobacillus helveticus. J. Dairy Sci. 86:3831-3840.

IDF. 1982. Cheese and Processed Cheese. Determination of the Total Solids Content. No. 4: A. Int. Dairy Fed., Brussels, Belgium.

IDF. 1993. Milk. Determinations of Nitrogen Content. No. 20: B. Int. Dairy Fed., Brussels, Belgium.

IDF. 1997. Milk and Milk Products. Determination of Fat Content (General Guidance on the Use of Butyrometric Methods). No. 152: A. Int. Dairy Fed., Brussels, Belgium.

Ismail, B., and S. S. Nielsen. 2010. Plasmin protease in milk: Current knowledge and relevance to dairy industry. J. Dairy Sci. 93:49995009 .

Iwanczak, M., and K. Wisniewska. 2005. Effect of high pressure on the process of Edam cheese proteolysis. High Press. Res. 25:43-50.

Juan, B., V. Ferragut, M. Buffa, B. Guamis, and A. J. Trujillo. 2007. Effects of high pressure on proteolytic enzymes in cheese: Relationship with the proteolysis of ewe milk cheese. J. Dairy Sci. 90:2113-2125.

Juan, B., V. Ferragut, B. Guamis, and A. J. Trujillo. 2008. The effects of high-pressure treatment at $300 \mathrm{MPa}$ on ripening of ewe's milk cheese. Int. Dairy J. 18:129-138.

Lawrence, R. C., L. K. Creamer, and J. Gilles. 1987. Texture development during cheese ripening. J. Dairy Sci. 70:1748-1760.

Malone, A. S., T. H. Shellhammer, and P. D. Courtney. 2002. High pressure effects on the viability, morphology, lysis and cell wall hydrolase activity of Lactococcus lactis ssp. cremoris. Appl. Environ. Microbiol. 68:4357-4363.

McSweeney, P. L. H. 2004. Biochemistry of cheese ripening. Int. J. Dairy Technol. 57:127-144.

Messens, W., K. Dewettinck, J. Van Camp, and A. Huyghebaert. 1998. High pressure brining of Gouda cheese and its effect on the cheese serum. Food Sci. Technol. (Campinas.) 31:552-558.
Messens, W., J. Estepas-Garcia, K. Dewettinck, and A. Huyghebaert. 1999. Proteolysis of high-pressure-treated Gouda cheese. Int. Dairy J. 9:775-782.

Messens, W., I. Foubert, K. Dewettinck, and A. Huyghebaert. 2001. Proteolysis of high-pressure-treated mould-ripened cheese. Milchwissenschaft 56:201-204.

Moschopoulou, E., T. Anisa, G. Katsaros, P. Taoukis, and G. Moatsou. 2010. Application of high-pressure on ovine brined cheese: Effect on composition and microflora throughout ripening. Innov. Food Sci. Emerg. Technol. 11:543-550.

O'Reilly, C. E., A. L. Kelly, P. M. Murphy, and T. P. Beresford. 2001. High-pressure treatment: Applications to cheese manufacture and ripening. Trends Food Sci. Technol. 12:51-59.

O'Reilly, C. E., A. L. Kelly, J. C. Oliveira, P. M. Murphy, M. A. E. Auty, and T. P. Beresford. 2003. Effect of varying high-pressure treatment conditions on acceleration of ripening of cheddar cheese. Innov. Food Sci. Emerg. Technol. 4:277-284.

O'Reilly, C. E., P. M. O'Connor, A. L. Kelly, T. P. Beresford, and P. M. Murphy. 2000. Use of hydrostatic pressure for inactivation of microbial contaminants in cheese. Appl. Environ. Microbiol. 66:4890-4896.

O'Reilly, C. E., P. M. O'Connor, P. M. Murphy, A. L. Kelly, and T. P. Beresford. 2002. Effects of high-pressure treatment on viability and autolysis of starter bacteria and proteolysis in cheddar cheese. Int. Dairy J. 12:915-922.

Ozturk, M., S. Govindasamy-Lucey, J. J. Jaeggi, K. Houck, M. E. Johnson, and J. A. Lucey. 2013a. Effect of various high-pressure treatments on the properties of reduced-fat Cheddar cheese. J. Dairy Sci. 96:6792-6806.

Ozturk, M., S. Govindasamy-Lucey, J. J. Jaeggi, M. E. Johnson, and J. A. Lucey. 2013b. The influence of high hydrostatic pressure on regular, reduced, low and no salt added Cheddar cheese. Int. Dairy J. 33:175-183.

Piraino, P., E. Parente, and P. L. H. McSweeney. 2004. Processing of chromatographic data for chemometric analysis of peptides from cheese extracts: A novel approach. J. Agric. Food Chem. 52:69046911.

Rampilli, M., and V. Raja. 1998. Osservazioni sull'atti- vitá di plasmina e plasminogeno nel formaggio. Sci. Tecn. Latt. Cas. 49:341350.

Richardson, B., and K. Pearce. 1981. The determination of plasmin in dairy products. N.Z. J. Dairy Sci. Tech. 16:209-220.

Rynne, N. M., T. P. Beresford, T. P. Guinee, E. Sheehan, C. M. Delahunty, and A. L. Kelly. 2008. Effect of high-pressure treatment of 1 day-old full-fat Cheddar cheese on subsequent quality and ripening. Innov. Food Sci. Emerg. Technol. 9:429-440.

Sadat-Mekmene, L., R. Richoux, L. Aubert-Frogerais, M. N. Madec, C. Corre, M. Piot, J. Jardin, S. le Feunteun, S. Lortal, and V. Gagnaire. 2013. Lactobacillus helveticus as a tool to change proteolysis and functionality in Swiss-type cheeses. J. Dairy Sci. 96:1455-1470.

Saldo, J., P. L. H. McSweeney, E. Sendra, A. L. Kelly, and B. Guamis. 2002. Proteolysis in caprine milk cheese treated by high pressure to accelerate cheese ripening. Int. Dairy J. 12:35-44.

Saldo, J., E. Sendra, and B. Guamis. 2000. High hydrostatic pressure for accelerating ripening of Goat's milk cheese: Proteolysis and texture. J. Food Sci. 65:636-640.

Saldo, J., E. Sendra, and B. Guamis. 2001. Hard cheese structure after a high hydrostatic pressure treatment at $50 \mathrm{MPa}$ for $72 \mathrm{~h}$ applied to cheese after brining. Lait 81:625-635.

Sheehan, J. J., T. Huppertz, M. G. Hayes, A. L. Kelly, T. P. Beresford, and T. P. Guinee. 2005. High pressure treatment of reduced-fat Mozzarella cheese: Effects on functional and rheological properties. Innov. Food Sci. Emerg. Technol. 6:73-81.

Sihufe, G. A., A. C. Rubiolo, and S. E. Zorrilla. 2012. Reggianito cheese: Hard cheese produced in Argentina. Pages 377-386 in Handbook of Animal-Based Fermented Food and Beverage Technology. CRC Press, Boca Raton, FL.

Sousa, M. J., Y. Ardö, and P. H. L. McSweeney. 2001. Advances in the study of proteolysis during cheese ripening. Int. Dairy J. 11:327345 
Torres, J. A., and G. Velazquez. 2005. Commercial opportunities and research challenges in the high pressure processing of food. J. Food Eng. 67:95-112.

Trujillo, A. J., M. Capellas, M. Bufa, C. Royo, R. Gervilla, X. Felipe, E. Sendra, J. Saldo, V. Ferragut, and B. Guamis. 2000. Application of high pressure treatment for cheese production. Food Res. Int. 33:311-316.

Vélez, M. A. 2013 Influence of indigenous milk enzymes activities lipoprotein lipase and plasmin on lipolysis and proteolysis of hard cooked cheeses. Doctoral Thesis. Facultad de Bioquímica y Ciencias Biológicas, Universidad Nacional del Litoral, Santa Fe, Argentina. Accessed Mar. 12, 2015. http://bibliotecavirtual.unl.edu. ar: $8180 /$ tesis/handle/ $1 / 577$.

Voigt, D. D., F. Chevalier, M. C. Qian, and A. L. Kelly. 2010. Effect of high-pressure treatment on microbiology, proteolysis, lipolysis and levels of flavour compounds in mature blue-veined cheese. Innov. Food Sci. Emerg. Technol. 11:68-77.

Wick, C., U. Nienaber, O. Anggraeni, T. H. Shellhammer, and P. D. Courtney. 2004. Texture proteolysis and viable lactic acid bacteria in commercial Cheddar cheeses treated with high pressure. J. Dairy Res. 71:107-115.

Yang, W., Y. Xub, D. Zhangc, Y. Zhaod, and Z. Zhao. 2014. Effects of high pressure treatments on the ripening of hard cheeses. Appl Mech. Mater. 464:98-102.

Yokoyama, H., N. Sawamura, and N. Motobayashi, inventors. 1992. Method for accelerating cheese ripening. European Patent application EP 469857 (0) A1.

Zannoni, M., L. Bertozzi, and E. A. Hunter. 1994. Comparison of Parmigiano-Reggiano and American Parmesan cheeses by sensory analysis of texture. Sci. Tecn. Latt. Cas. 45:505-518. 